\title{
Periosteal distraction as bone regenerative alternative.
}

\author{
Mario Pérez-Sayáns García ${ }^{*}$, José Manuel Martínez Martín ${ }^{2}$, Mercedes Gallas Torreira², María del \\ Mar Mata Martínez ${ }^{3}$, Abel García-García ${ }^{4}$ \\ ${ }^{1}$ Oral Medicine, Oral Surgery and Implantology Unit, Instituto de Investigación Sanitaria de Santiago (IDIS), Santiago \\ de Compostela, Spain
}

${ }^{2}$ Master de Medicina Oral, Cirugía oral e Implantología, University of Santiago de Compostela. Santiago de Compostela, Spain

${ }^{3}$ Master de Ortodoncia y Ortopedia Dentofacial, University of Santiago de Compostela. Santiago de Compostela, Spain

${ }^{4}$ Professor of Maxillofacial Surgery, Master de Medicina Oral, Cirugía oral e Implantología, University of Santiago de Compostela. Department of Maxillofacial Surgery, Complejo Hospitalario Universitario de Santiago de Compostela, Spain

\begin{abstract}
The use of endoseus implants is frequently limited by insufficient bone in the reception area as a result of trauma, tooth loss, poor surgical technique or periodontal disease. Several methods have been described to solve problems related to bone atrophy: regeneration with bone grafts, Guided Bone Regeneration (GBR) and Osteogenic Distraction (OD). OD is a technique that induces the formation of hard and soft tissue through a progressive elongation of a gap created by osteotomy. The periosteum plays an active role in osteogenic distraction. Therefore, it is possible to produce the formation of new bone through Osteogenetic Periosteal Distraction (OPD) without having to perform an osteotomy. The goal of this revision is to clarify the matter, revising the used devices, techniques and comparing the results. The bibliographic revision of OPD was performed by searching on PUBMED and SCOPUS for the articles published until December 2013. We included a total of 17 articles that complied with the requirements. Several experimental studies in animals have shown the formation of bone by OPD, however, there is not a clear protocol to develop the intervention due to the diversity of devices, animal models, anatomical regions or variables in the surgical technique in regards to latency periods, activation frequency and consolidation periods. OPD is efficient for the creation of new bone between the remnant bone and the periosteal tissue, although the amount of variables do not allow for the establishment of a predictable result.
\end{abstract}

Keywords: Endoseus implants, Osteogenic distraction, Osteogenetic periosteal distraction, Periosteum.

\section{Introduction}

The use of endoseus implants for partial or complete dental restorations has gained popularity over the last decades, showing great reliability over time. There are some minimal requirements of tridimensional space for implant placement. However, implant placement depending on the designed prosthetic position frequently has the problem of insufficient bone in the reception area as a result of trauma, tooth loss, poor surgical technique or periodontal disease. Long-term prognosis for dental implants is negatively affected by an insufficient bone volume [1].

Several methods have been described to solve problems related to bone atrophy: (a) regeneration with bone grafts [2-4] (b) Guided Bone Regeneration (GBR) [5-12] (c) Osteogenic
Distraction (OD) $[13,14]$. The 'Gold Standard' in regeneration still is the placement of an autogenous bone, although it has inconveniences such as morbidity of the donating location, resorption and being a limited bone. GBR is one of the most broadly used techniques. Its main inconvenience is the healing period until achieving a complete rehabilitation. OD is a technique that induces the formation of hard and soft tissue through a progressive elongation of a gap created by osteotomy. It has proven to be a predictable technique in certain treatments with great crest vertical deficiency. However, the indications for alveolar OD can be limited depending on the resorption type and state of the alveolar crest. In addition to being a technique requiring great experience.

The periosteum plays an active role in osteogenic distraction through a very vascularized internal region, called the 
osteoblastic layer. This layer is composed of mesenchymal stem cells that can be differentiated in osteoblasts $[15,16]$. Although the application of distracting forces through OD leads to the formation of sub-periosteal bone, tension in the periosteum is enough to create significant amounts of subperiosteal bone [17]. Therefore, it is possible to produce the formation of new bone through Osteogenetic Periosteal Distraction (OPD) without having to perform an osteotomy [18-36].

The surgical technique consists of placing a distraction device under the healthy periosteum. After a variable latency period, we proceed with the activation of the device, which continues to elevate the periosteum until reaching the desired height. Subsequently, it is left during a consolidation period, so the bone may mature.

Several experimental studies in animals have shown the formation of bone by OPD, however, there is not a clear protocol to develop the intervention due to the diversity of devices, animal models, anatomical regions or variables in the surgical technique in regards to latency periods, activation frequency and consolidation periods [18-36].

The goal of this revision is to clarify the matter, revising the used devices, techniques and comparing the results.

\section{Material and Methods}

The bibliographic revision of periosteal distraction was performed by searching on PUBMED and SCOPUS for the articles published until December 2013. The keywords used were the following: 'Periosteal AND distraction AND regeneration'. Since this technique is still under research, we included all experimental studies in animals. The articles were classified in the table detailing sample sizes, animal models, type of device used, latency period, activation frequency, consolidation period, height obtained, occupation of the newly formed bone and region. We also analysed the complications and observations of the authors.

\section{Results}

After searching on PUBMED and SCOPUS, we included a total of 17 articles that complied with the requirements of experimental studies on animals. The animals of the experiment were rats, rabbits, mini pigs and dogs. The devices were tested in several anatomic regions, as shown in Table 1. Different periosteal distraction devices were used, the most frequent ones were devices 1a-1c (Figure 1); and devices represented in Figure 2, correspond to other types of devices used only once.

In regards to the surgical technique, since there is such a variability of specimens and devices, it was very diverse. All the techniques share the device bone anchoring, with a fair preservation of the periosteum. The latency, activation and consolidation periods also differed in different studies. The average latency period was $6.85 \mathrm{~d}$, the maximum latency period was $14 \mathrm{~d}$ and the minimum was $1 \mathrm{~d}$. The most common activation was $0.5 \mathrm{~mm} / \mathrm{d}$, varying from $0.1 \mathrm{~mm} / \mathrm{d}$ until $1 \mathrm{~mm} / \mathrm{d}$ during an average period of $11 \mathrm{~d}(5-32 \mathrm{~d})$. The average consolidation period was $33.7 \mathrm{~d}(7-90 \mathrm{~d})$.

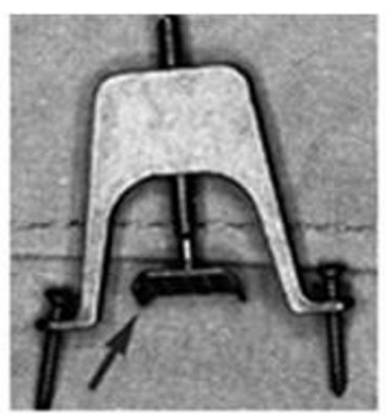

a
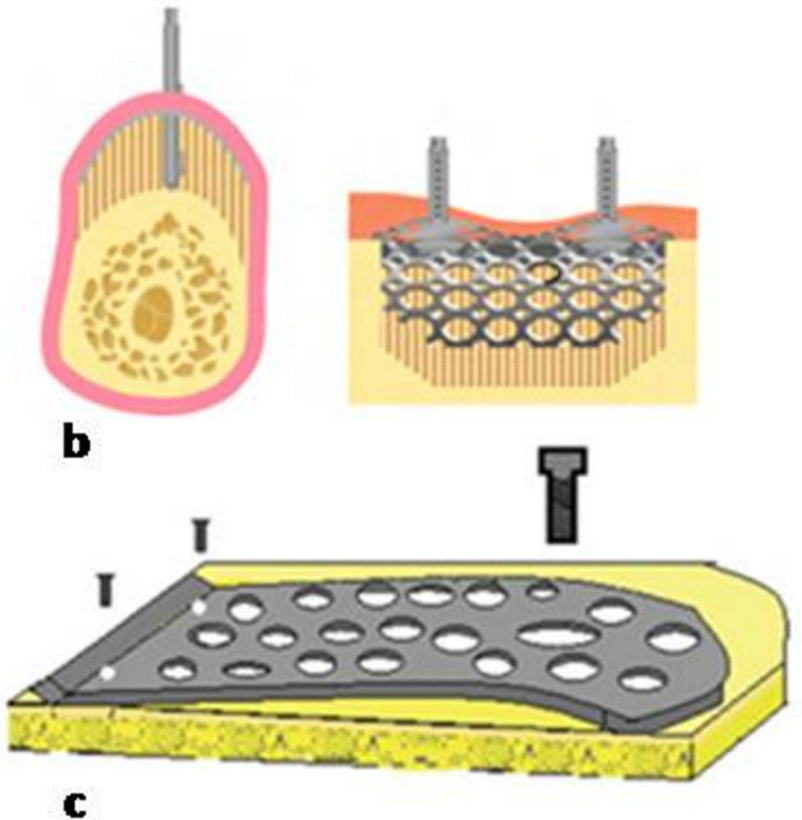

Figure 1. Main devices. Device 1a: U-shaped device with two legs for anchoring surface using two micro screws. Synthes Maxillofacial design, Paolic, PA. It was used four times. Device 1b: Micro titanium mesh of $30 \times 30 \mathrm{~mm}$ and $0.25 \mathrm{~mm}$ thick, prepared for anchoring two screws. KLS Martin, Tuttlinger, Germany. It was used twice. Device 1c: Titanium mesh $20 \times 10 \mathrm{~mm}$ and $0.3 \mathrm{~mm}$ thickness. Uses two screws and a screw distractor was used four times.

The height was described in 4 articles, the average was 3.22 $\mathrm{mm}$. The maximum height achieved was $7.2 \mathrm{~mm}$ in a trial developed on rabbits by Sato et al. [30] with the device described as number 4 . The minimum height achieved was 1.4 $\mathrm{mm}$ in a study by Casap et al. [35], also in rabbits but using device number 1 .

The occupation percentage of the new bone regarding the total space was $42.81 \%$, measurement taken in 6 studies. The highest average bone occupation was $66.33 \%$ in a study by Tudor et al. [24] in mini pigs, using device number 2. The lowest bone occupation was $29.2 \%$ in the article published by Yamauchi et al. [20], using an auto-expandable device.

The area was also measured in 6 studies, in $\mathrm{mm}^{2}, \mathrm{~cm}^{2}$ and $\mathrm{mm}^{3}$. The highest average area was obtained in the study by 
Altug et al. [36] in a study of the mandibular branch in rabbits, with an average of $2.94 \mathrm{~cm}^{2}$.
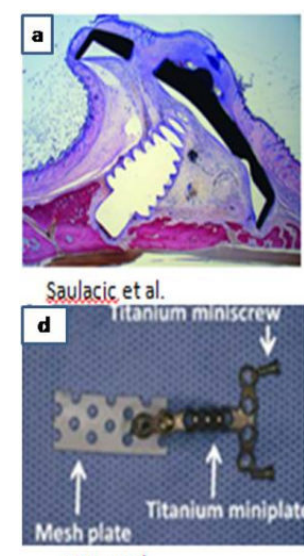

Sato et al.

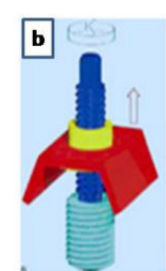

Estrada et al.

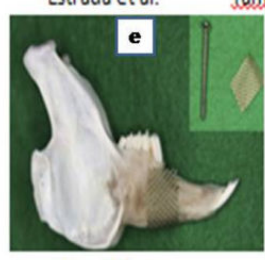

Oda et al.

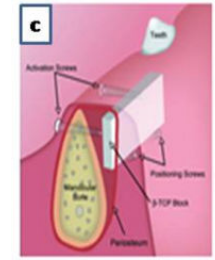

Yamauchi et al. 2009

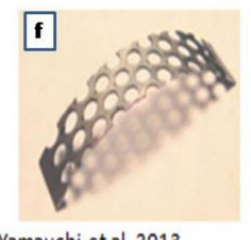

Yamauchi et al. 2013

Figure 2. Other devices (a-f).

In two studies by Yamauchi et al. [22,23] developed in dogs, the device created a horizontal increase. Sencimen et al. [25] compared the DPO with the OD, using the same device, with a newly formed bone area of $14.4 \mathrm{~mm}^{2}$ and $25.4 \mathrm{~mm}^{2}$, respectively. The study developed by Estrada et al. [34], was not valid due to an inappropriate design of the device. Oda et al. [31] and Saulacic et al. [29] created different groups perforating and not perforating the bone cortical, obtaining better results in the groups with perforations. In a study by Saluacic et al. [28] they used the device in a group covered by a collagen membrane and Casap et al. [35] used VEGF in a group and obtained a better result in bone formation.

The most common complication was inflammation. Cases of infection, mobility of devices and death of specimens were reported $[26,29,35]$, but in most cases the goal was achieved.

Table 1. Summary of experimental studies in periosteal distraction.

\begin{tabular}{|c|c|c|c|c|c|c|c|c|c|c|c|}
\hline Author & $\begin{array}{l}\text { Samp } \\
\text { le }\end{array}$ & $\begin{array}{l}\text { Animal } \\
\text { model }\end{array}$ & $\begin{array}{l}\text { Anatomi } \\
\text { c area }\end{array}$ & $\begin{array}{l}\text { Dis } \\
\text { p. }\end{array}$ & $\begin{array}{l}\text { Latency } \\
\text { (w) }\end{array}$ & Activation & $\begin{array}{l}\text { Consolidat } \\
\text { ion }\end{array}$ & Height & $\begin{array}{l}\% \quad \text { Total } \\
\text { bone/Area }\end{array}$ & Area & Details \\
\hline \multirow[t]{3}{*}{ Nakahara et al. } & 30 & Rat & Calvarian & 4 & 7 & $\begin{array}{l}0.1 \mathrm{~mm} / 24 \\
\mathrm{~h} / 10 \mathrm{~d}\end{array}$ & $\begin{array}{l}17,31 \text { and } \\
45 \mathrm{~d}\end{array}$ & & $\begin{array}{l}11.41 \quad \pm \\
4.05(17 d)^{ \pm}\end{array}$ & & \\
\hline & & & & & & & & & $\begin{array}{l}13.96 \quad \pm \\
2.46(31 \mathrm{~d})\end{array}$ & & \\
\hline & & & & & & & & & $\begin{array}{l}30.64 \quad \pm \\
1.48(45 d)\end{array}$ & & \\
\hline \multirow[t]{4}{*}{ Yamauchi et al. } & 12 & Rabbit & Frontal & 1 & & & 5 & & $\begin{array}{l}\text { Control: } \\
6.1 \pm 1.54\end{array}$ & & $\begin{array}{l}\text { With (case)/ } \\
\text { without (control) } \\
\text { Dynamic } \\
\text { elevation }\end{array}$ \\
\hline & & & & & & & & & $\begin{array}{l}\text { Case: } 21.9 \\
\pm 5.33\end{array}$ & & \\
\hline & & & & & & & 8 & & $\begin{array}{l}\text { Control: } \\
15.5 \pm 4.04\end{array}$ & & \\
\hline & & & & & & & & & $\begin{array}{l}\text { Case: } 36.0 \\
\pm 7.11\end{array}$ & & \\
\hline \multirow[t]{2}{*}{ Nakahara et al } & 24 & Rat & Calvarian & 1 & 7 & $0.1 / 24 \mathrm{~h} / 10 \mathrm{~d}$ & 10 & & & $\begin{array}{l}\text { Periosteum } \\
10.81 \mathrm{~mm}^{3}\end{array}$ & $\begin{array}{l}\text { No differences } \\
\text { with/without } \\
\text { membrane } \\
\text { barrier }\end{array}$ \\
\hline & & & & & & & & & & $\begin{array}{l}\text { Periosteum } \\
2.12 \mathrm{~mm}^{3}\end{array} \quad(-) \quad 3.49 \pm$ & \\
\hline $\begin{array}{l}\text { Dziewiecki et } \\
\text { al. }\end{array}$ & 12 & Minipig & Calvarian & 4 & & & $\begin{array}{l}12,28 \text { and } \\
42 \mathrm{~d}\end{array}$ & & $\begin{array}{l}34.75 \\
28.16\end{array}$ & $53.1 \pm 31.5 \mathrm{~mm}^{3}$ & \\
\hline \multirow[t]{2}{*}{ Saulacic et al. } & 60 & Rabbit & Calvarian & 1 & 7 & $\begin{array}{l}0.25 \mathrm{~mm} / 24 \\
\mathrm{~h} / 10 \mathrm{~d}\end{array}$ & $\begin{array}{l}10, \quad 17 \\
24,31 \text { and } \\
77\end{array}$ & $\begin{array}{l}\text { Asymmet } \\
\text { rical }\end{array}$ & & & $\begin{array}{l}\text { PCR analysis } \\
\text { (BMP-2, RUNX2, } \\
\text { ACP5, SPARC, } \\
\text { collagen la1, } \\
\begin{array}{l}\text { collagen Ila1, } \\
\text { and SOX9) }\end{array}\end{array}$ \\
\hline & & & & & & $\begin{array}{l}0.5 \mathrm{~mm} / 24 \\
\mathrm{~h} / 10 \mathrm{~d}\end{array}$ & & & & & \\
\hline
\end{tabular}




\begin{tabular}{|c|c|c|c|c|c|c|c|c|c|c|c|}
\hline $\begin{array}{l}\text { Kahraman et } \\
\text { al. }\end{array}$ & 20 & Rabbit & $\begin{array}{l}\text { Inferolater } \\
\text { al surface } \\
\text { mandible }\end{array}$ & 4 & 7 & $\begin{array}{l}0.35 \mathrm{~mm} / 24 \\
\mathrm{~h} / 10 \mathrm{~d}\end{array}$ & 45 & & $\begin{array}{l}66.0 \pm 5.7 \\
\text { case }\end{array}$ & $\begin{array}{l}34.6 \pm 7.4 \mathrm{~mm} / \mathrm{mm}^{2} 36.0 \\
\pm 9.8 \mathrm{~mm} / \mathrm{mm}^{2}\end{array}$ & $\begin{array}{l}\text { Local } \\
\text { Simvastatim vs. } \\
\text { control }\end{array}$ \\
\hline & & & & & & & & & $\begin{array}{l}57.5 \pm 6.5 \\
\text { control }\end{array}$ & & \\
\hline Suer et al. & 24 & Rabbit & $\begin{array}{l}\text { Lateral } \\
\text { surface } \\
\text { mandible }\end{array}$ & 1 & 7 & $\begin{array}{l}0.25 \\
\mathrm{~mm} / 12 \mathrm{~h} / 1 \mathrm{~d}\end{array}$ & $16-32$ & & & & HBO vs. NBO \\
\hline \multirow[t]{2}{*}{ Yamauchi et al. } & 12 & Rabbit & Frontal & 4 & 14 & & 35 & & $27.3 \pm 10.8$ & $2.14 \pm 0.85 \mathrm{~cm}^{2}$ & \\
\hline & & & & & 14 & & 56 & & $31.1 \pm 12.1$ & $2.90 \pm 1.13 \mathrm{~cm}^{2}$ & \\
\hline \multirow[t]{2}{*}{ Zacaria et al. } & 12 & Rabbit & Shell & 3 & 7 & $\begin{array}{ll}0.5 & \mathrm{~mm} / 12 \\
\mathrm{~h} / 5 \mathrm{~d} & \end{array}$ & 28 & & 38.64 & & \\
\hline & & & & & 7 & $\begin{array}{ll}0.5 & \mathrm{~mm} / 12 \\
\mathrm{~h} / 5 \mathrm{~d} & \end{array}$ & 42 & & 54.99 & & \\
\hline \multirow[t]{2}{*}{ Zacaria et al. } & 8 & Rabbit & Shell & 3 & 7 & $\begin{array}{ll}0.5 & \mathrm{~mm} / 12 \\
\mathrm{~h} / 5 \mathrm{~d} & \end{array}$ & 24 & & 44.36 & & \\
\hline & & & & & 7 & $\begin{array}{ll}0.5 & \mathrm{~mm} / 12 \\
\mathrm{~h} / 5 \mathrm{~d} & \end{array}$ & 42 & & 60.16 & & \\
\hline \multirow[t]{3}{*}{ Saulacic et al. } & 32 & Rats & Shell & 3 & 7 & $\begin{array}{l}0.1 \mathrm{~mm} / 24 \\
\mathrm{~h} / 10 \mathrm{~d}\end{array}$ & 14 & & & Yes & \\
\hline & & & & & 7 & & 28 & & & & \\
\hline & & & & & 7 & & 42 & & & & \\
\hline Saulacic et al. & 48 & Rats & Shell & 3 & 7 & $\begin{array}{l}0.2 \mathrm{~mm} / 24 \\
\mathrm{~h} / 10 \mathrm{~d}\end{array}$ & 7 & & & yes & \\
\hline \multirow[t]{2}{*}{ Saulacic et al. } & 16 & Rats & Shell & 4 & 7 & $\begin{array}{l}0.4 \mathrm{~mm} / 24 \\
\mathrm{~h} / 10 \mathrm{~d}\end{array}$ & 10 & $\begin{array}{l}2.07 \\
0.62\end{array}$ & \pm & $862.16 \pm 18.3 \mathrm{~mm}^{3}$ & \\
\hline & & & & & 7 & $\begin{array}{l}0.4 \mathrm{~mm} / 24 \\
\mathrm{~h} / 10 \mathrm{~d}\end{array}$ & 20 & $\begin{array}{l}2.13 \\
0.46\end{array}$ & \pm & $860.09 \pm 10.0 \mathrm{~mm}^{3}$ & \\
\hline \multirow[t]{2}{*}{ Altug et al. } & 36 & Rabbit & Ramus & 1 & 7 & $\begin{array}{l}0.25 \mathrm{~mm} / 12 \\
\mathrm{~h} / 10 \mathrm{~d}\end{array}$ & $15-30-60$ & & & $2.62 \mathrm{~cm}^{2}$ & \\
\hline & & & & & 1 & $\begin{array}{l}0.25 \mathrm{~mm} / 12 \\
\mathrm{~h} / 10 \mathrm{~d}\end{array}$ & $15-30-60$ & & & $3.26 \mathrm{~cm}^{2}$ & \\
\hline Yamauchi et al. & 5 & Dogs & Ramus & 4 & 8 & $0.5 \mathrm{~mm} / \mathrm{d} / 6 \mathrm{~d}$ & 56 & & & & B-TCP Block \\
\hline \multirow[t]{3}{*}{ Tudor et al } & 9 & Minipig & Frontal & 2 & 3 & $\begin{array}{ll}0.5 & \mathrm{~mm} / 12 \\
\mathrm{~h} / 5 \mathrm{~d} & \end{array}$ & $14-28-42$ & & $71-95-69 \%$ & & \\
\hline & & & & & 3 & $\begin{array}{l}0.5 \mathrm{~mm} / 12 \\
\mathrm{~h} / 10 \mathrm{~d}\end{array}$ & $14-28-42$ & & $52-33-80 \%$ & & \\
\hline & & & & & 3 & $\begin{array}{l}0.5 \mathrm{~mm} / 12 \\
\mathrm{~h} / 15 \mathrm{~d}\end{array}$ & $14-28-42$ & & $30-85-82 \%$ & & \\
\hline \multirow[t]{2}{*}{ Sato et al } & 8 & Rabbit & Parietal & 4 & 7 & $\begin{array}{l}0.5 \mathrm{~mm} / \mathrm{d} / 20 \\
\mathrm{~d}\end{array}$ & 21 & $\begin{array}{l}7.20 \\
0.96\end{array}$ & \pm & $153.7 \pm 15.3 \mathrm{~mm}^{3}$ & Control \\
\hline & & & & & 7 & & 21 & $\begin{array}{l}5.20 \\
0.95\end{array}$ & & $92.2 \pm 13.8 \mathrm{~mm}^{3}$ & \\
\hline \multirow[t]{4}{*}{ Oda et al } & 25 & Rabbit & Ramus & 4 & 7 & $0.5 \mathrm{~mm} / \mathrm{d} / 8 \mathrm{~d}$ & 28 & & $\begin{array}{l}46.9 \\
7.3 \%\end{array}$ & $13.5 \pm 3.2 \mathrm{~mm}^{2}$ & $\begin{array}{l}6 \\
\text { perforation }\end{array}$ \\
\hline & & & & & 7 & & 28 & & $\begin{array}{l}41.3 \quad \pm \\
6.3 \%\end{array}$ & $11 \pm 2.9 \mathrm{~mm}^{2}$ & $\begin{array}{l}6 \quad \text { without } \\
\text { perforstion }\end{array}$ \\
\hline & & & & & 7 & & 56 & & $\begin{array}{l}86.6 \quad \pm \\
12.2 \%\end{array}$ & $25.7 \pm 5.1 \mathrm{~mm}^{2}$ & $\begin{array}{l}7 \quad \text { with } \\
\text { perforation }\end{array}$ \\
\hline & & & & & 7 & & 56 & & $\begin{array}{l}46.6 \quad \pm \\
8.9 \%\end{array}$ & $12.9 \pm 3.2 \mathrm{~mm}^{2}$ & $\begin{array}{l}6 \quad \text { without } \\
\text { perforation }\end{array}$ \\
\hline
\end{tabular}




\begin{tabular}{|c|c|c|c|c|c|c|c|c|c|c|c|}
\hline Yamauchi et al. & 3 & Dog & Ramus & 4 & 8 & $0.5 \mathrm{~mm} / \mathrm{d} / 8 \mathrm{~d}$ & 56 & & & Yes & B-TCP Block \\
\hline & & & & & 8 & & 56 & & & & \\
\hline \multirow[t]{2}{*}{ Casap et al. } & 10 & Rabbit & Ramus & 1 & 14 & $1 \mathrm{~mm} / \mathrm{d} / 7 \mathrm{~d}$ & 60 & 1.4 & $2.50 \%$ & & VEGF \\
\hline & & & & & 14 & & 60 & 1.7 & $13 \%$ & & \\
\hline Sencimen et al. & 18 & Rabbit & Ramus & 1 & 7 & $\begin{array}{l}0.25 \mathrm{~mm} / 12 \\
\mathrm{~h} / 10 \mathrm{~d}\end{array}$ & $15-30-60$ & & & $8.5-17.8-16.8 \mathrm{~mm}^{2}$ & \\
\hline Kessler et al. & 6 & Minipig & Frontal & 2 & 5 & $\begin{array}{l}0.5 \mathrm{~mm} / \mathrm{d} / 10 \\
\mathrm{~d}\end{array}$ & $7-17-45$ & & $\begin{array}{l}39,70-58 \\
6-90 \%\end{array}$ & & \\
\hline \multirow[t]{2}{*}{ Estrada et al. } & 12 & Rabbit & & 4 & 10 & $\begin{array}{l}0.25 \mathrm{~mm} / \mathrm{d} / 32 \\
\mathrm{~d}\end{array}$ & $10-20-30$ & & & & \\
\hline & & & & & 10 & $\begin{array}{l}0.5 \mathrm{~mm} / \mathrm{d} / 16 \\
\mathrm{~d}\end{array}$ & $10-20-30$ & & & & \\
\hline Estrada et al. & 4 & Dog & Ramus & 4 & 10 & $\begin{array}{l}0.2 \mathrm{~mm} / \mathrm{d} / 22 \\
\mathrm{~d}\end{array}$ & 90 & & & & \\
\hline Schmidt et al. & 10 & Rabbit & Ramus & 1 & 7 & $\begin{array}{l}1 \mathrm{~mm} / 3 \mathrm{~d} / 15 \\
\mathrm{~d}\end{array}$ & $\begin{array}{l}28-35-42-5 \\
6\end{array}$ & $\begin{array}{l}2.86 \\
0.56\end{array}$ & \pm & & \\
\hline
\end{tabular}

HBO: Hyperbaric Oxygen; NBO: Non-Hyperbaric Oxygen.

\section{Discussion}

The reconstruction of bone loss in the alveolar border is complex, since the deformity includes a deficiency of both the bone and the mucosa. Different techniques have been used to solve this deficiency. Alveolar osteogenic distraction has shown to be a viable and predictable variable for this type of situations [37]. However, OD requires the use of osteotomy which is difficult to develop in narrow crests and some complications such as ingestions, deviation of the inclination vector, fragment sequestration or fractures [38]. For these reasons, there are several studies that have evaluated the formation of new bone through the distraction of the periosteum, without having to develop an osteotomy, facilitating the surgical treatment and decreasing the possible complications deriving from the creation of a transport fragment.

The results of this study show that a constant tension in the periosteum at a certain frequency is sufficient for the creation of new bone between the remnant bone and the periosteal tissue. The review compares 17 articles in which they have used this technique in several animal models (rats, rabbits, mini pigs and dogs) and all of these studies resulted in the formation of new bone in greater or lower measure.

Different device designs were used, despite that bone regeneration or neoformation was achieved, we cannot highlight one design over another. To develop this intra-oral technique, the best design is similar to number 2, used by Kesser et al. [33], through the possible adaptation of the anatomy of a edentulous alveolar crest. In the next study we will propose a new device design that can be perfectly adapted to the intra-oral anatomy.

In addition to the variability of devices, different studies have tested several latency, activation and consolidation periods.
Most of the studies agree in the importance of a latency period of approximately $7 \mathrm{~d}$, necessary to achieve a good healing of the tissue, we cannot start the distraction without a healthy mucosa, otherwise we would be exposed to the deshicense of the flap with the subsequent failure of the technique. The activation frequencies have been very varied, the most frequent one was $0.5 \mathrm{~mm} / \mathrm{d}$, although since there are different animal models (rats, rabbits, mini pigs and dogs), the measure should be extrapolated to each animal group. Despite this fact, the complications by dehicences were very infrequent. The consolidation period also has great variations between the different studies, in most of the studies different consolidation periods took place for the histomorphometric analysis of the bone in different maturity phases. In general, a higher average consolidation period achieved a greater percentage of bone per area. Kessler et al. [33] tested consolidation periods of 7, 17 and $45 \mathrm{~d}$, obtaining percentages of 39.7, 58.9 and $90 \%$, respectively. In 2 studies Zacaria et al. [18,19], assessed the percentage of bone per total area in consolidation times of 28 and 42; and of 24 and $42 \mathrm{~d}$, resulting in a greater formation of bone percentage in longer consolidation periods.

The average height was $3.22 \mathrm{~mm}$, the maximum height achieved was $7.2 \mathrm{~mm}$ by Sato et al. [30] with the device described as number 4, the minimum height was $1.4 \mathrm{~mm}$ achieved by Casap et al. [35] with the device described was number 1, both studies were developed in rabbits. This information shows that there are great quantitative differences when developing the technique with one device or another.

\section{Conclusions}

The results of this study show that periosteal distraction is efficient for the creation of new bone between the remnant bone and the periosteal tissue. The amount of variables (devices, species, operating times...) do not allow for the 
establishment of a predictable result. More studies are necessary as well as the improvement of devices adapted to each anatomical region.

\section{Acknowledgements}

Not applicable.

\section{Disclosures}

There are not any financial interests.

\section{References}

1. Lekholm U, Adell R, Lindhe J, Brånemark PI, Eriksson B, Rockler B, Lindvall AM, Yoneyama T. Marginal tissue reactions at osseointegrated titanium fixtures. (II) A crosssectional retrospective study. Int J Oral Maxillofac Surg 1986; 15: 53-61.

2. Soutar DS, McGregor IA. The radial forearm flap in intraoral reconstruction: the experience of 60 consecutive cases. Plast Reconstr Surg 1986; 78: 1-8.

3. Swartz WM, Banis JC, Newton ED, Ramasastry SS, Jones NF, Acland R. The osteocutaneous scapular flap for mandibular and maxillary reconstruction. Plast Reconstr Surg 1986; 77: 530-545.

4. Taylor GI. Reconstruction of the mandible with free composite iliac bone grafts. Ann Plast Surg 1982; 9: 361-376.

5. Dahlin C, Andersson L, Linde A. Bone augmentation at fenestrated implants by an osteopromotive membrane technique. A controlled clinical study. Clin Oral Implants Res 1991; 2: 159-165.

6. Dahlin C, Linde A, Gottlow J, Nyman S. Healing of bone defects by guided tissue regeneration. Plast Reconstr Surg 1988; 81: 672-676.

7. Dahlin C, Sennerby L, Lekholm U, Linde A, Nyman S. Generation of new bone around titanium implants using a membrane technique: an experimental study in rabbits. Int J Oral Maxillofac Implants 1989; 4: 19-25.

8. Kostopoulos L, Karring T. Guided bone regeneration in mandibular defects in rats using a bioresorbable polymer. Clin Oral Implants Res 1994; 5: 66-74.

9. Kostopoulos L, Karring T, Uraguchi R. Formation of jawbone tuberosities by guided tissue regeneration. An experimental study in the rat. Clin Oral Implants Res 1994; 5: 245-253.

10. Nyman SR, Lang NP. Guided tissue regeneration and dental implants. Periodontol 2000 1994; 4: 109-118.

11. Hammerle $\mathrm{CH}$, Jung RE, Feloutzis A. A systematic review of the survival of implants in bone sites augmented with barrier membranes (guided bone regeneration) in partially edentulous patients. J Clin Periodontol 2002; 29: 226-231.

12. Hämmerle $\mathrm{CH}$, Schmid J, Olah AJ, Lang NP. A novel model system for the study of experimental guided bone formation in humans. Clin Oral Implants Res 1996; 7 : $38-47$.

13. Ilizarov GA. The tension-stress effect on the genesis and growth of tissues. Part I. The influence of stability of fixation and soft-tissue preservation. Clin Orthop Relat Res 1989; 249-281.

14. Ilizarov GA. The tension-stress effect on the genesis and growth of tissues: Part II. The influence of the rate and frequency of distraction. Clin Orthop Relat Res 1989; 263-285.

15. Ozerdem OR, Kivanc O, Tuncer I, Acarturk S, Gocenler L, Gumurdulu D. Callotasis in nonvascularized periosteal bone grafts and the role of periosteum: a new contribution to the concept of distraction osteogenesis. Ann Plast Surg 1998; 41: 148-155.

16. Popowics TE, Zhu Z, Herring SW. Mechanical properties of the periosteum in the pig, Sus scrofa. Arch Oral Biol 2002; 47: 733-741.

17. Kostopoulos L, Karring T. Role of periosteum in the formation of jaw bone. An experiment in the rat. J Clin Periodontol 1995; 22: 247-254.

18. Zakaria O, Madi M, Kasugai S. Induced osteogenesis using a new periosteal distractor. J Oral Maxillofac Surg 2012; 70: 225-234.

19. Zakaria O, Kon K, Kasugai S. Evaluation of a biodegradable novel periosteal distractor. J Biomed Mater Res B Appl Biomater 2012; 100: 882-889.

20. Yamauchi K, Takahashi T, Tanaka K, Nogami S, Kaneuji T, Kanetaka H. Self-activated mesh device using shape memory alloy for periosteal expansion osteogenesis. J Biomed Mater Res B Appl Biomater 2013; 101: 736-742.

21. Yamauchi K, Takahashi T, Funaki K, Yamashita Y. Periosteal expansion osteogenesis using highly purified beta-tricalcium phosphate blocks: a pilot study in dogs. J Periodontol 2008; 79: 999-1005.

22. Yamauchi K, Takahashi T, Funaki K, Miyamoto I, Yamashita Y. Implant placement for periosteal expansion osteogenesis using beta-tricalcium phosphate block: an experimental study in dogs. Oral Surg Oral Med Oral Pathol Oral Radiol Endod 2009; 108: 861-866.

23. Yamauchi K, Takahashi T, Funaki K, Hamada Y, Yamashita Y. Histological and histomorphometrical comparative study of beta-tricalcium phosphate block grafts and periosteal expansion osteogenesis for alveolar bone augmentation. Int J Oral Maxillofac Surg 2010; 39: 1000-1006.

24. Tudor C, Bumiller L, Birkholz T, Stockmann P, Wiltfang J, Kessler P. Static and dynamic periosteal elevation: a pilot study in a pig model. Int J Oral Maxillofac Surg 2010; 39: 897-903.

25. Sencimen M, Aydintug YS, Ortakoglu K, Karslioglu Y, Gunhan O, Gunaydin Y. Histomorphometrical analysis of new bone obtained by distraction osteogenesis and osteogenesis by periosteal distraction in rabbits. Int $\mathrm{J}$ Oral Maxillofac Surg 2007; 36: 235-242. 
26. Schmidt BL, Kung L, Jones C, Casap N. Induced osteogenesis by periosteal distraction. J Oral Maxillofac Surg 2002; 60: 1170-1175.

27. Saulacic N, Schaller B, Iizuka T, Buser D, Hug C, Bosshardt DD. Analysis of New Bone Formation Induced by Periosteal Distraction in a Rat Calvarium Model. Clin Implant Dent Relat Res 2013; 15: 283-291.

28. Saulacic N, Schaller B, Bosshardt DD, Buser D, Jaun P, Haeniwa $H$. Periosteal distraction osteogenesis and barrier membrane application: an experimental study in the rat calvaria. J Periodontol 2012; 83: 757-765.

29. Saulacic N, Hug C, Bosshardt DD, Schaller B, Buser D, Haeniwa H. Relative contributions of osteogenic tissues to new bone formation in periosteal distraction osteogenesis: histological and histomorphometrical evaluation in a rat calvaria. Clin Implant Dent Relat Res 2013; 15: 692-706.

30. Sato K, Haruyama N, Shimizu Y, Hara J, Kawamura H. Osteogenesis by gradually expanding the interface between bone surface and periosteum enhanced by bone marrow stem cell administration in rabbits. Oral Surg Oral Med Oral Pathol Oral Radiol Endod 2010; 110: 32-40.

31. Oda T, Kinoshita K, Ueda M. Effects of cortical bone perforation on periosteal distraction: an experimental study in the rabbit mandible. J Oral Maxillofac Surg 2009; 67: 1478-1485.

32. Lethaus B, Tudor C, Bumiller L, Birkholz T, Wiltfang J, Kessler P. Guided bone regeneration: dynamic procedures versus static shielding in an animal model. J Biomed Mater Res B Appl Biomater 2010; 95: 126-130.

33. Kessler P, Bumiller L, Schlegel A, Birkholz T, Neukam FW, Wiltfang J. Dynamic periosteal elevation. Br J Oral Maxillofac Surg 2007; 45: 284-287.
34. Estrada JI, Saulacic N, Vazquez L, Lombardi T, Ramirez JU, Bernard JP. Periosteal distraction osteogenesis: preliminary experimental evaluation in rabbits and dogs. Br J Oral Maxillofac Surg 2007; 45: 402-405.

35. Casap N, Venezia NB, Wilensky A, Samuni Y. VEGF facilitates periosteal distraction-induced osteogenesis in rabbits: a micro-computerized tomography study. Tissue Eng Part A 2008; 14: 247-253.

36. Altug HA, Aydintug YS, Sencimen M, Gunhan O, Ortakoglu K, Bayar GR. Histomorphometric analysis of different latency periods effect on new bone obtained by periosteal distraction: an experimental study in the rabbit model. Oral Surg Oral Med Oral Pathol Oral Radiol Endod 2011; 111: 539-546.

37. Saulacic N, Iizuka T, Martin MS, Garcia AG. Alveolar distraction osteogenesis: a systematic review. Int $\mathrm{J}$ Oral Maxillofac Surg 2008; 37: 1-7.

38. Saulacic N, Somosa Martín M, De Los Angeles Leon Camacho M, Garcia Garcia A. Complications in alveolar distractionosteogenesis: A clinical investigation. J Oral Maxillofac Surg 2007; 65: 267.

\section{*Correspondence to}

Mario Pérez-Sayáns García

Oral Medicine

Oral Surgery and Implantology Unit

Instituto de Investigación Sanitaria de Santiago (IDIS)

Spain 